\title{
The New Paradox of Thrift:
}

Financialisation, retirement protection, and income polarisation in Hong Kong

Kim Ming Lee, Benny Ho-pong To and Kar Ming Yu

\section{(2) OpenEdition}

\section{Journals}

Electronic version

URL: http://journals.openedition.org/chinaperspectives/6363

DOI: 10.4000/chinaperspectives.6363

ISSN: 1996-4617

\section{Publisher}

Centre d'étude français sur la Chine contemporaine

\section{Printed version}

Date of publication: 1 March 2014

Number of pages: 5-14

ISSN: 2070-3449

\section{Electronic reference}

Kim Ming Lee, Benny Ho-pong To and Kar Ming Yu, « The New Paradox of Thrift: », China Perspectives [Online], 2014/1 | 2014, Online since 01 January 2017, connection on 28 October 2019. URL : http:// journals.openedition.org/chinaperspectives/6363; DOI : 10.4000/chinaperspectives.6363 


\title{
The New Paradox of Thrift
}

\author{
Financialisation, retirement protection, and income polarisation in Hong Kong
}

\author{
KIM MING LEE, BENNY HO-PONG TO, AND KAR MING YU
}

\begin{abstract}
The Hong Kong SAR government has always been proud of the fact that Hong Kong retains its top ranking in terms of "market freedom" according to most international rating agencies and think tanks. What the government has been much more reluctant to recognise is that, more than 15 years after the handover, Hong Kong now also tops other developed economies in terms of income inequality. The growing inequality is caused, among other things, by worsening poverty among the aged. This paper attempts to provide an updated analysis of income and wealth polarisation in Hong Kong, with a particular focus on the retirement protection policy and old-age poverty. It will examine the polarising effects of the financialisation of the Hong Kong economy.
\end{abstract}

KEYWORDS: Financialisation, asset-based welfare, pension fund capitalism, public housing, retirement protection, income polarisation, old-age poverty.

M ost of the literature tends to attribute income polarisation in Hong Kong to the economic restructuring since the 1980 s, especially the deskilling of middle-aged workers. While important, such analysis overlooks the role of financialisation, especially its impact on social protection. Financialisation is a global phenomenon, and appreciation of this factor in the Hong Kong context is crucial for explaining why several policy initiatives, such as the Mandatory Provident Fund (MPF), have generated a new "paradox of thrift": encouraging more saving and investment economy-wide has paradoxically led to worse prospects for the lower class. (1) This article intends to fill this gap.

This article will proceed as follows. First, we will review the current literature about financialisation, pension fund capitalism, and asset-based welfare. Then, drawing from various official data, we will attempt to demonstrate how financialisation transforms and shapes the economy, government policies, and social polarisation. In particular, we will look at the impact of financialisation on public housing and retirement protection in Hong Kong. Different as they would seem, we will show that government policies in both policy areas can be understood by the same logic of financialisation. We will conclude with an overall evaluation of the effects of financialisation on inequality, especially poverty among the elderly. It will be argued that there is a dire need for social welfare reform, especially in the pension system, to deal with the current polarisation.

\section{Financialisation and pension fund capitalism}

Capitalism has transformed itself in successive stages with different institutional characteristics. The economic stagnation in the 1970s, the rise of neoliberalism and the processes of globalisation in the 1980s demonstrated the failure of Fordism and signified transition to a new form of capitalism. In particular, scholars have focused on the phenomenon of financialisation, especially since the Global Financial Crisis. The idea of financialisation cuts across different disciplines and approaches, each with its own emphasis. However, all point to the importance of finance in contemporary capitalism and its adverse consequences, especially for the poor and disadvantaged groups. In this paper, financialisation is defined as "the increasing role of financial motives, financial markets, financial actors, and financial institutions in the operation of the domestic and international economies." (2) It is manifested in "the greater autonomy of the financial sector, the proliferation of financial institutions and instruments, and the integration of a broad range of economic actors in financial markets." "(3) This new phase of capitalism has been known variously as finance-led growth regime, money-manager capitalism, or simply financialised capitalism.

In an increasingly financialised world, banks are no longer the main players in finance. Corporations that traditionally reinvest either through internal retained earnings or bank loans can now raise funds via new financial channels: stock markets and the so-called institutional investors, comprised of investment banks, pension funds, mutual funds, hedge funds, and structured investment vehicles. Their interests are in dividends and capital gains rather than in the operation of corporations, ${ }^{(4)}$ thus transforming the corporate world by re-setting profitability norms to evaluate firms through the shareholder value movement. ${ }^{(5)}$ In order to attract institutional investors, firms employ short-term strategies of manipulating low-debt balance sheet to avoid financing long-term production projects. ${ }^{(6)}$ Meanwhile, there is a shift away from traditional management methods that stabilise industrial relations, such as long-term employment and collective bargaining, to flexible

1. We are borrowing from the "old" paradox of thrift, a key concept in Keynesian macroeconomics, which argues that an increase in collective saving paradoxically reduces aggregate demand and therefore total output of the economy. While Keynes's focus is on the aggregate and ours on the distributional, the two paradoxes are similar in reminding us that economy-wide saving is not always beneficial.

2. Gerald A. Epstein, "Introduction: Financialisation and the World Economy," in Gerald A. Epstein (ed), Financialisation and the World Economy, Cheltenham, Edward Elgar, 2005, p. 3.

3. Alex Callinicos, Bonfire of Illusions: The Twin Crises of the Liberal World, Polity, 2013, p. 34.

4. Matthew Watson, "Investigating the Potentially Contradictory Microfoundations of Financialisation," Economy and Society, Vol. 38, No. 2, 2009, pp. 255-277.

5. William Lazonick and Mary O'sullivan, "Maximising Shareholder Value: A New Ideology for Corporate Governance," Economy and Society, Vol. 29, No. 1, 2000, pp. 13-35.

6. Matthew Watson, "Investigating the Potentially Contradictory Microfoundations of Financialisation," art. cit., pp. 262-264; Robert Boyer, "Assessing the Impact of Fair Value Upon Financial Crises," Socio-Economic Review, Vol. 5, No. 4, 2007, pp. 779-807. 
management and outsourcing that is believed to enhance efficiency and productivity. As a result, the labour market is destabilised, wages are depressed, and workers face higher economic insecurity and wage stagnation. Job insecurity and wage stagnation not only imply worsening living conditions for workers, but also dampen aggregate demand.

Especially noteworthy among the institutional investors are pension funds, whose influence on nation-states and the global economy has been so significant that some have described it as "pension fund capitalism." (7) The changes from defined benefit (DB) to defined contribution (DC) plans ${ }^{(8)}$ in the pension system in the 1970s helped to transform corporate governance into a system dominated by shareholder's interests. (9) In DB plans, employers shoulder the responsibility for ensuring the viability of the funds, but in DC plans, the responsibility is shifted to capital markets. Many firms also found that their DB plans accumulated more assets than needed to pay their workers, and therefore terminated the DB plans to turn the excess assets into corporate profits. ${ }^{(10)}$ The change in the private pension landscape is a key factor behind the rise of institutional investors in developed economies. ${ }^{(11)}$ The boom in private pension funds has fuelled capital market inflation and financialisation.

Pension funds typically exhibit a lifecycle in which large inflows of contributions from beneficiaries take place at the beginning, but the situation reverses in the mature period, when outflow pension payments are higher than inflow contributions. Unless the economy is growing steadily and pensionable employment is rising, pension schemes typically mature in 20 to 30 years. If a large number of pension schemes approach maturity simultaneously, there is a risk that, with insufficient investment opportunities, fund managers will be forced to sell their assets to pay policyholders. ${ }^{(12)}$ With net excess outflow from the markets, asset prices inevitably fall and hurt the returns of funds, and even lead to system-wide financial crisis. To avoid this, many countries have sought to attract new cash inflows through financial innovations or directing funds to "unexplored" markets. The "solution" is to financialise, in principle, everything from which "exchange value" can be extracted and turned into financial assets. The most important categories are social welfare and property.

\section{Welfare financialisation and the social investment state}

Concomitant with the trend of financialisation is the discourse on assetbased welfare in social policy, which advocates turning the welfare state into a social investment state. ${ }^{(13)}$ Its basic assumption is that people are well placed to utilise their assets and exercise choice in the pursuit of their livelihoods because they have the necessary skills and information to benefit from their asset building. ${ }^{(14)}$ Although the idea of the social investment state focuses on human and social capital and encouraging savings to meet future life course risks, it has been extended by the neoliberal state to the realm of property and financial assets, strategically promoting the finance-led growth regime. For instance, Jacob Hacker described attempts by the American state to privatise state-sponsored social insurance as the "great risk shift": the shift of responsibility for managing economic risk from the government and employers to individuals and their families. ${ }^{(15)}$ Through the gradual dismantling of the social protection system by cutting public social services and privatising social insurance systems, individuals and households are required to insure against their life-course risks by turning to private insurers and financial markets for economic security.
Besides turning social insurance entitlements into private investments, neoliberal states actively privatise public service provisions to boost further financialisation. According to Andrew Leyshon and Nigel Thrift, the main characteristic of finance capitalism is the constant searching out or constructing of new assets that can yield a predictable income stream. The assets can then either be used as collateral for borrowing new capital to finance investment or speculating in riskier assets, or be securitised to found a financial base for further speculation. ${ }^{(16)}$ Privatised social welfare and service provisions, notably pensions, housing, and medical services, become important targets for financialisation because of their predictable income streams. Indeed, "any form of privatisation has the potential to induce financialisation since it creates a stream of revenue that can be consolidated into assets that can become part of a derivative that is speculatively traded." (17)

In brief, the advance of asset-based welfare or welfare financialisation has led people to rely not on the state but on investments in financial products and property to protect themselves from life contingencies. Nonetheless, ordinary people are not professional investors who are competent to accumulate sufficient wealth. Hence, neoliberal governments have promoted the education of financial literacy to instil an investor identity in the entire population. ${ }^{(18)}$ Furthermore, when traditional banking loses its profitability, commercial banks also aggressively engage in financial activities. With the abolition of the 1933 Glass-Steagall Act in the US, commercial banks operate like investment banks and promote various financial investments to their clients through their extensive retailing networks and electronic banking systems. As a result, ordinary people have more convenient ways to engage in various financial activities.

In a financialised economy, financial transactions dominate economic exchanges. Financialisation has changed the behaviour and priority of ordinary people, including welfare recipients. Moreover, asset building and wealth

7. Gordon L. Clark, Pension Fund Capitalism, Oxford, Oxford University Press, 2000

8. In a DB plan, the employee's benefit is determined by a formula that takes into account years of service for the employer and salary history. The employer bears investment risk and is responsible for portfolio management. In a DC plan, each employee has an account into which the employer and, usually, the employee make regular contributions. Benefits depend on the total contributions and returns on investments in the account. Thus, the employee bears investment risk. See Zvi Bodie, Alan J. Marcus, and Robert C. Merton, "Defined Benefit versus Defined Contribution Pension Plans: What are the Real Trade-offs?", in Zvi Bodie, John B. Shoven, and David A. Wise (eds), Pensions in the U.S. Economy, Chicago, University of Chicago Press, 1988, pp.139-162.

9. Martin Gelter, "The Pension System and the Rise of Shareholder Primacy," Seton Hall Law Review, Vol. 43, No. 3, 2013, pp. 909-70.

10. Ibid., pp. 923-936

11. Ibid., pp. 963-968

12. Jan Toporowski, The End of Finance: Capital Market Inflation, Financial Derivatives and Pension Fund Capitalism, New York, Routledge, 2002, ch. 5.

13. Michael Sherraden, Assets and the Poor: A New American Welfare Policy, Armonk, M.E. Sharpe, 1991; Michael Sherraden, "From a Social Welfare State to a Social Investment State," in Claire Kober and Will Paxton (eds), Asset-Based Welfare and Poverty: Exploring the Case for and against Asset-Based Welfare Policies, London, Institute for Public Policy Research, 2002, pp. 5-8.

14. Anis A. Dani and Caroline Moser, "Asset-Based Social Policy and Public Action in a Polycentric World," in Caroline Moser and Anis A. Dani (eds), Assets, Livelihoods, and Social Policy, Washington, World Bank, 2008, p. 6

15. Jacob S. Hacker, The Great Risk Shift: Why American Jobs, Families, Health Care and Retirement Aren't Secure - and How We Can Fight Back, New York, Oxford University Press, 2006.

16. Andrew Leyshon and Nigel Thrift, "The Capitalisation of Almost Everything: The Future of Finance and Capitalism," Theory, Culture \& Society, Vol. 24, No. 7/8, 2007, pp. 97-115.

17. Ben Fine, "Financialisation and Social Policy," in Peter Razavi, Shahrashoub Buchholz, and Rebecca Varghese Utting (ed), The Global Crisis and Transformative Social Change, Basingstoke, Palgrave Macmillan, 2012, p. 105.

18. Julie Froud et al., "The Quiet Panic About Financial Illiteracy," in Libby Assassi et al. (eds), Global Finance in the New Century: Beyond Deregulation, London, Palgrave Macmillan, 2007. 
Table 1 - Gross Domestic Product (GDP) by selected economic activity - percentage contribution to GDP at basic prices (2000-2011)

\begin{tabular}{|l|c|c|c|c|c|c|c|c|c|c|c|c|c|}
\hline Economic Activity & 2000 & 2001 & 2002 & 2003 & 2004 & 2005 & 2006 & 2007 & 2008 & 2009 & 2010 & 2011 \\
\hline Construction & 4.9 & 4.5 & 4.1 & 3.7 & 3.2 & 2.8 & 2.7 & 2.5 & 3.0 & 3.2 & 3.3 & 3.4 \\
\hline Import/export, wholesale, and retail trades & 21.6 & 22.2 & 22.8 & 23.6 & 25.0 & 26.1 & 24.9 & 23.6 & 24.6 & 23.4 & 23.8 & 25.9 \\
\hline Financing and insurance & 12.8 & 12.1 & 12.3 & 13.3 & 13.1 & 13.8 & 16.7 & 20.1 & 17.1 & 16.2 & 16.4 & 16.1 \\
\hline Real estate & 5.0 & 4.6 & 4.3 & 4.0 & 4.1 & 4.4 & 4.3 & 4.5 & 5.2 & 5.5 & 5.1 & 5.6 \\
\hline Ownership of premises & 10.8 & 11.3 & 11.2 & 10.7 & 9.8 & 10.1 & 10.3 & 9.9 & 11.0 & 11.5 & 10.6 & 10.2 \\
\hline FIRE* & 33.5 & 32.5 & 31.9 & 31.7 & 30.2 & 31.1 & 34.0 & 37.0 & 36.3 & 36.4 & 35.4 & 35.3 \\
\hline $\begin{array}{l}\text { Construction, real estate and ownership of } \\
\text { premises }\end{array}$ & 20.7 & 20.4 & 19.6 & 18.4 & 17.1 & 17.3 & 17.3 & 16.9 & 19.2 & 20.2 & 19.0 & 19.2 \\
\hline
\end{tabular}

* FIRE includes construction, financing and insurance, real estate, and ownership of premises.

Source: Census and Statistics Department, www.censtatd.gov.hk/hkstat/sub/sp250.jsp (accessed on 5 February 2014).

Table 2 - Composite employment estimates by selected industries, 2000 to 2011

\begin{tabular}{|l|c|c|c|c|c|c|c|c|c|c|c|c|c|}
\hline Industry & 2000 & 2001 & 2002 & 2003 & 2004 & 2005 & 2006 & 2007 & 2008 & 2009 \\
\hline \multirow{2}{*}{ Construction } & 302200 & 289400 & 283900 & 261400 & 263000 & 264300 & 270800 & 275200 & 265900 & 261200 & 261500 & 271900 \\
& $(9.4 \%)$ & $(8.9 \%)$ & $(8.8 \%)$ & $(8.2 \%)$ & $(8.0 \%)$ & $(7.9 \%)$ & $(7.9 \%)$ & $(7.9 \%)$ & $(7.6 \%)$ & $(7.5 \%)$ & $(7.5 \%)$ & $(7.6 \%)$ \\
\hline $\begin{array}{l}\text { Import/export, wholesale } \\
\text { and retail trades }\end{array}$ & 834400 & 835900 & 824700 & 833900 & 868000 & 899400 & 908900 & 916800 & 909800 & 881000 & 884900 & 888200 \\
& $(26.0 \%)$ & $(25.7 \%)$ & $(25.6 \%)$ & $(26.1 \%)$ & $(26.5 \%)$ & $(26.9 \%)$ & $(26.6 \%)$ & $(26.3 \%)$ & $(25.9 \%)$ & $(25.4 \%)$ & $(25.4 \%)$ & $(24.8 \%)$ \\
\hline Financing and insurance & 169100 & 178100 & 176000 & 167900 & 169400 & 179400 & 186000 & 192700 & 206100 & 211400 & 216700 & 226300 \\
& $(5.3 \%)$ & $(5.5 \%)$ & $(5.5 \%)$ & $(5.2 \%)$ & $(5.2 \%)$ & $(5.4 \%)$ & $(5.4 \%)$ & $(5.5 \%)$ & $(5.9 \%)$ & $(6.1 \%)$ & $(6.2 \%)$ & $(6.3 \%)$ \\
\hline Real estate & 91600 & 92700 & 93700 & 94800 & 94900 & 101800 & 106800 & 110100 & 116200 & 113600 & 115000 & 122100 \\
& $(2.9 \%)$ & $(2.8 \%)$ & $(2.9 \%)$ & $(3.0 \%)$ & $(2.9 \%)$ & $(3.0 \%)$ & $(3.1 \%)$ & $(3.2 \%)$ & $(3.3 \%)$ & $(3.3 \%)$ & $(3.3 \%)$ & $(3.4 \%)$ \\
\hline Public administration, & 698600 & 738200 & 756000 & 773500 & 785700 & 792500 & 812300 & 835700 & 847500 & 869600 & 873700 & 916000 \\
and social and personal services & $(21.8 \%)$ & $(22.7 \%)$ & $(23.4 \%)$ & $(24.2 \%)$ & $(24.0 \%)$ & $(23.7 \%)$ & $(23.8 \%)$ & $(24.0 \%)$ & $(24.1 \%)$ & $(25.1 \%)$ & $(25.1 \%)$ & $(25.6 \%)$ \\
\hline Total employment & 3211600 & 3255600 & 3223900 & 3200500 & 3279100 & 3343000 & 3412100 & 3480500 & 3509800 & 3470300 & 3478600 & 3579500 \\
\hline
\end{tabular}

Source: Composite Employment Estimates, Census and Statistics Department, various years.

creation have been so infused into the popular culture that ordinary people have become obsessed with improving their lives through financial and property investment. (19) This culture of financialisation is established through corporate media and financial journalism. ${ }^{(20)}$ As financialisation, through neoliberal state and mass media, induces consent from ordinary people about individual responsibility of building assets and wealth to insure against personal or familial risks, it has tremendous implications for changes in welfare, which we will now examine through the case of Hong Kong.

\section{The financialisation of the Hong Kong economy}

Hong Kong has long been an international financial centre. According to the Global Financial Centres Index, Hong Kong is now ranked number three, just behind London and New York, in the latest 2013 ranking. ${ }^{(21)}$ However, before the 1980s, the Hong Kong economy was driven by manufacturing rather than FIRE (finance, insurance, and real estate). Since China adopted its Open Door policy, Hong Kong has experienced deindustrialisation and economic restructuring. Against this context, capitalists and policymakers intentionally or unintentionally transformed and financialised the Hong Kong economy.

In this section, we attempt to show the extent of Hong Kong's financialisation by examining its FIRE sectors. From Table 1, we can see that trading is still the single most important sector contributing to the Hong Kong economy. However, the FIRE sectors, taken as a whole, have become the engine of growth and contribute to around one third of Hong Kong's GDP. Right before the Global Financial Crisis, FIRE reached its peak in 2007, constituting $37.0 \%$ of GDP. Alan Smart and James Lee note that real estate

19. Randy Martin, Financialisation of Daily Life, Philadelphia, Temple University Press, 2002.

20. Cathy Greenfield and Peter Williams, "Financialisation, finance rationality and the role of media in Australia," Media, Culture \& Society, Vol. 29, No. 3, 2007, pp. 415-433.

21. Mark Yeandle and Chiara von Gunten, The Global Financial Centres Index 13, London, Z/Yen Group, 2013. 


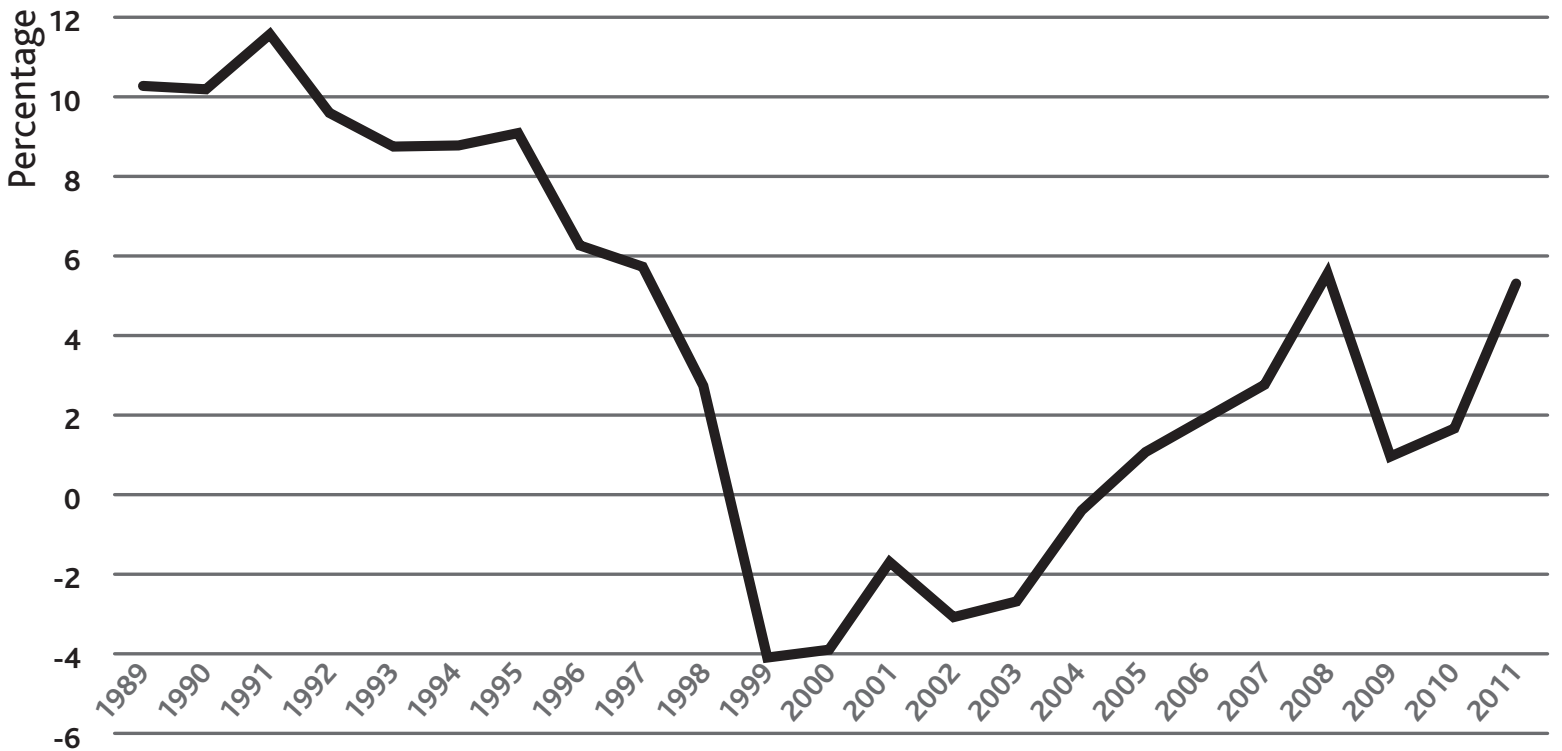

Source: Annual Report on the Consumer Price Index, Census and Statistics Department, various years.

plays a more significant role than the finance and insurance sectors in propelling growth in HK's financialised economy. (22) Jean Jaulin and JeanFrançois Huchet argue that a property-led growth model has taken place since the mid-1980s. ${ }^{(23)}$ Haila describes the Hong Kong state as a property state that relies on property to generate government revenue, supplement other financial markets (as property is a highly leveraged financial asset), and stimulate economic growth. It also gives rise to a group of powerful developers, who deploy their land profits to telecommunication and other businesses to foster an informational Hong Kong economy. (24)

Although the FIRE sectors contribute heavily to GDP, their employment impact is relatively small. Table 2 shows that they employ around $17 \%$ of the total workforce. If construction is excluded, the employment rate is just about $9 \%$. The biggest sectors are trading, public administration, and social and personal services, which together employ approximately half of the total workforce. Thus, the growth of FIRE does not directly contribute much to employment, but it contributes indirectly by increasing government revenue and stimulating household consumption through wealth effects.

The property and stock market booms before the handover were induced by the high inflation rate (see Graphs 1 to 4 ) coupled with low nominal interest rates, which made the real interest rate basically negative. As asset prices rose, a positive feedback loop occurred because of the intrinsic animal spirits, à la Keynes, of human nature: people had strong incentive to use their savings and borrow from banks to invest or most likely speculate in the real estate and stock markets. The property and stock market euphoria drove people from, in Minskian terms, hedge to speculative or even Ponzi financial positions. ${ }^{(25)}$ The 1997 Asian financial crisis and the SARS outbreak made a lot of people bankrupt and turned people's property into negative equity. Nonetheless, the gradual liberalisation and development of China's capital markets due to its accession to the World Trade Organisation resurrected Hong Kong's financial markets and then its real estate.

The stock and property markets picked up momentum from 2004-2005 onwards. There was a setback during the Clobal Financial Crisis, but the Hong Kong economy was not fatally hurt because Hongkongers had learnt much from the 1997 crisis. The financial markets have not yet returned to their heyday before the global financial turmoil. Daily trading values are lower because most share prices have been depreciated considerably. Although daily trading volumes have returned to former levels, the volatility is greater. However, the property market is booming again (see Graphs 2 to 4) due to quantitative easing in the US, the European Union, and Japan, the fiscal expansion of China, super-low interest rates, and a rising inflation rate (see Graph 1).

\section{The financialisation of public housing}

The Hong Kong state plays a substantial role in financialising the economy. On the one hand, it has been creating an investment environment responsive to the interests of finance and property. On the other hand, as Boyer argues, the state's role in a finance-led economy is to stabilise the FIRE sectors and avoid building asset bubbles. Hence, the state is inevitably forced at times to counteract FIRE interests so as to maintain legitimacy and social stability. The risk of overheating in the property and stock markets has been a concern of the government and the Hong Kong Monetary Authority since the global financial catastrophe. Since stock and property markets have become the main income sources and profitable investment opportunities for all major economic players, any dramatic downturn of the markets would immediately translate into a politically sensitive and socially disruptive issue and seriously affect the governability of Hong Kong.

22. Alan Smart and James Lee, "Financialisation and the Role of Real Estate in Hong Kong's Regime of Accumulation," Economic Geography, Vol. 79, No. 2, 2003, pp. 153-71.

23. Jean Jaulin and Jean-François Huchet, "Hong Kong and the Asian Crisis: Growth Model Fails to Deliver," China Perspectives, No. 18, 1998, pp. 17-27.

24. Anne Haila, "Real Estate in Global Cities: Singapore and Hong Kong as Property States," Urban studies Vol. 37, No. 12, 2000, pp. 2241-2256.

25. A hedge position implies that the investor is able to pay back the principal and interests. In a speculative position, the investor can only pay interest and needs to roll over the debt. A Ponzi position simply means the investor cannot even service the interest and is in danger of insolvency. See Hyman P. Minsky, "The Financial Instability Hypothesis," The Jerome Levy Economics Institute Working Paper, No. 74, 1992. 


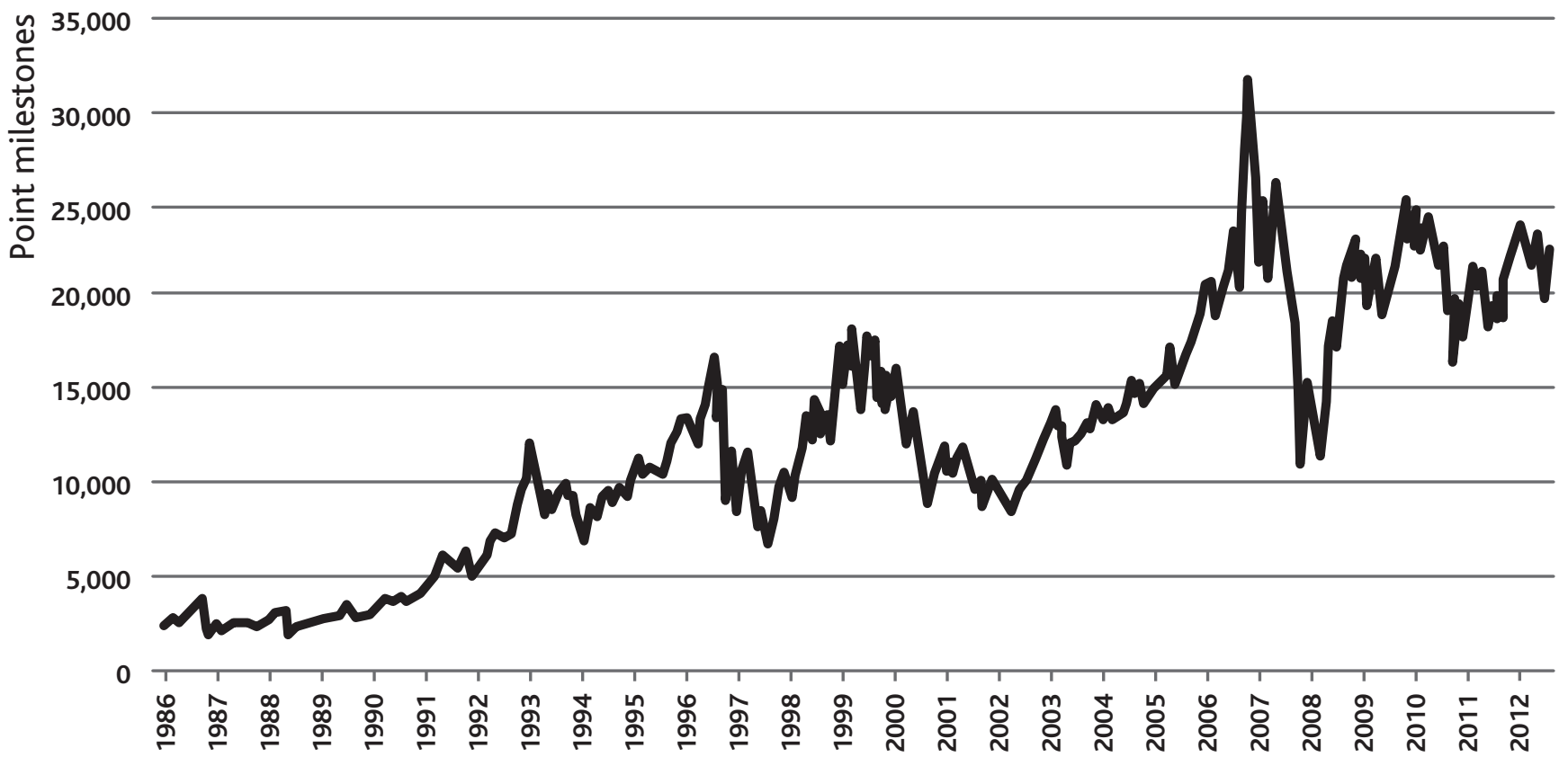

Source: Hong Kong Exchanges and Clearing Limited, www.hkex.com.hk/eng/stat/smstat/statarch/statarchive.htm (accessed on 5 February 2014).

Public housing, a hallmark of Hong Kong social welfare, is a case in point. As a productivist welfare regime, Hong Kong has always subsumed social policy under the growth imperative. (26) Employing neoliberal rhetoric, the state emphasises "welfare just for the poor and needy" and privatises welfare, allowing capitalists to expropriate lower classes of their social rights. As early as the late 1970s, for example, the government started to launch various subsidised home ownership schemes. Despite its noble objective of providing affordable quality housing, some suggest the underlying reason was that the private property markets failed to respond to the housing needs of the emerging new middle classes. ${ }^{(27)}$ In order to bridge the exchange-value-based property markets and the use-value-based public rental housing, the government inserted the subsidised schemes to create a housing ladder for the middle classes to enter the private markets. Moreover, the schemes also provided Housing Authority funds to finance public rental housing. The strategic use of subsidised homeownership to stabilise housing markets is well illustrated by the SAR government. Right after the handover, Chief Executive $\mathrm{C}$. H. Tung attempted to cool down the housing bubble with the now infamous " 85,000 " housing programme. However, the Asian financial turmoil and the SARS crisis completely destroyed his plan. Under tremendous pressure from land developers, Tung abandoned subsidised homeownership to support the private markets. ${ }^{(28)}$ Now, with the danger of another housing bubble amidst complaints over high rental and housing prices, the new Chief Executive, C.Y. Leung, has recommenced the schemes.

With regard to public rental housing, the government has launched a series of measures to make sure that housing is not a right but a commodity. For instance, in 2007, the government introduced a new public housing rental mechanism to replace the previous statutory $10 \%$ median rent-toincome ratio cap. The new mechanism allows flexible rent adjustments according to changes in tenants' household income. ${ }^{(29)}$ The measure was formulated after the government halted the subsidised homeownership schemes. Once the schemes stopped, the Housing Authority, as a financially independent statutory body, was confronted with funding problems to erect more housing to satisfy the housing needs of the poor. Thus, the new mechanism was proposed to drain resources from existing tenants to provide housing for the needy on the waiting list.

Another prominent case of financialising property is the setup of the Link REIT (Link hereafter). The Link is the first real estate investment trust (REIT) listed in Hong Kong. It is also Asia's biggest REIT. Establishing the Link was supposed to deal with the funding problems of the Housing Authority in the early 2000s. The Authority sold its retail and car-parking facilities in public housing estates to an investment trust, which would then be securitised and listed in the stock market. The deal was a replication of the earlier success in $\mathbf{2 0 0 0}$ of the partial privatisation of the Mass Transit Railway, which is not only a transportation company, but also a real estate developer. A few radical groups and politicians criticised the divestment, and a 67-yearold public housing tenant filed a judicial review to challenge the initial public offering (IPO) on the grounds that the privatisation would seriously affect the livelihood of public housing residents. Moreover, the critics argued that the Authority sold the facilities to the Link at such a low price that the tenants were subsidising the shareholders. ${ }^{(30)}$ Although the IPO was delayed, the Link was finally relisted in 2005 and is now controlled and managed by institutional investors. Once the Link was listed, under the logic of shareholder rather than stakeholder values, rents were quickly raised. Public housing residents had to pay higher prices for products and services sold in the

26. Ian Holliday, "Productivist Welfare Capitalism: Social Policy in East Asia," Political Studies, Vol. 48, No. 4, 2000, pp. 706-23.

27. The discussion on the housing issue is drawn from the authors' interviews with several housing rights advocates.

28. Alice Poon, Land and the Ruling Class in Hong Kong, Hong Kong, Enrich Professional Publishing, 2010.

29. Hong Kong Housing Authority, Report on The Review of Domestic Rent Policy, www.housingauthority.gov.hk/hdw/en/aboutus/policy/cdrp06/index.html (accessed on 24 September 2013). 


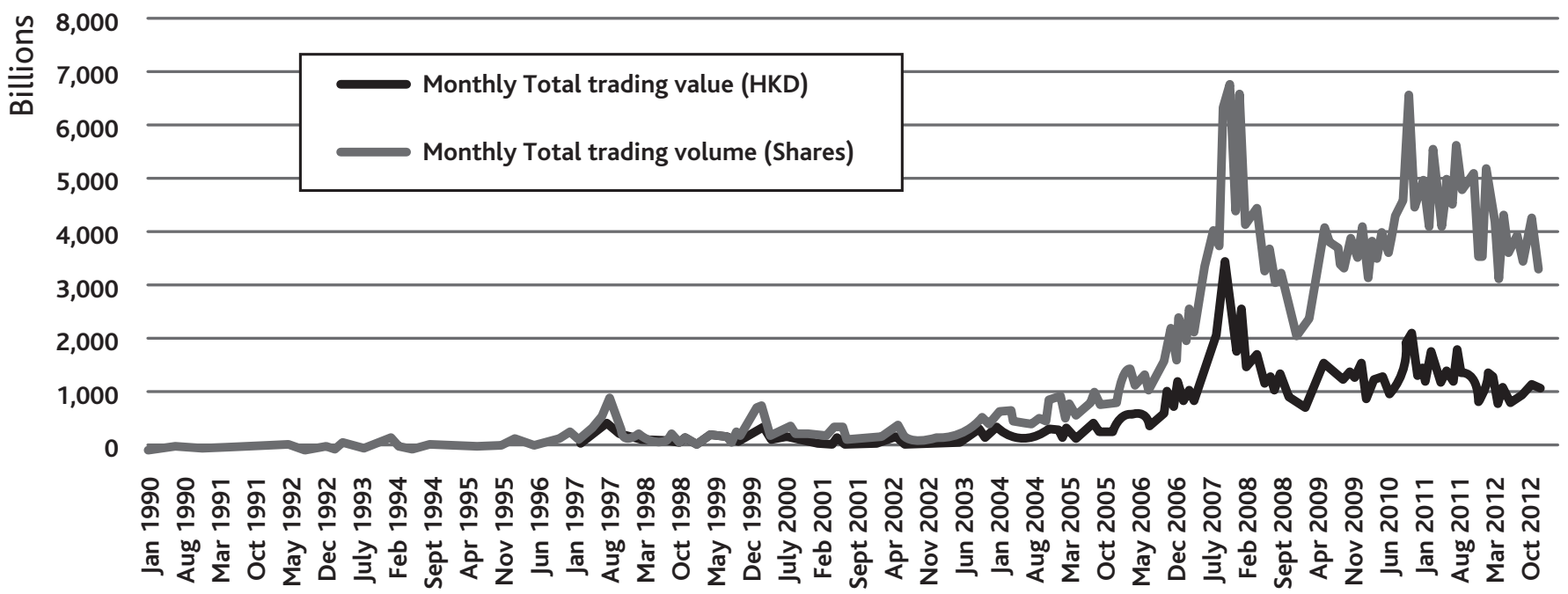

Source: Hong Kong Exchanges and Clearing Limited, www.hkex.com.hk/eng/stat/smstat/statarch/statarchive.htm (accessed on 5 February 2014).

shopping centres controlled by the Link. The share price of the Link rose from its IPO price of HK\$10.3 to its highest closing price of HK\$45.4 on 15 May 2013. ${ }^{(31)}$

\section{The financialisation of retirement protection}

Although public pensions have existed for a long time in Western countries, Hong Kong has debated setting up some form of retirement protection since the 1960s. As early as 1966, the colonial government embarked on a study of the feasibility of establishing a Central Provident Fund (CPF) in Hong Kong. The same issue was debated in the mid-1970s, late-1980s, and 1991, but as in 1966, all were rejected by the conservative business sector due to additional labour costs. (32) Moreover, the government did not favour it because "the volume of funds that would be under centralized control for investment purposes might have a major unsettling effect on the financial, monetary and foreign exchange markets." (33) After rejecting the CPF in 1991, the colonial government proposed a compulsory Retirement Protection Scheme (RPS), similar to the Mandatory Provident Fund (MPF) scheme implemented in 2000. It failed to materialise because the government refused to provide funding to guarantee a minimum benefit level. (34) In 1993, with the support of the last governor, Chris Patten, the government proposed a compulsory contributory Old Age Pension Scheme (OPS) that would provide a flat-rate monthly pension for all eligible elderly. Nonetheless, under strong opposition from the business sectors, together with pressure from Beijing, Patten abandoned the OPS and opted for the MPF. ${ }^{(35)}$

The direct implication of the implementation of MPF is the sudden inflow of money into the financial markets. From its inception in 2000 to the end of 2010, a total net amount of HK\$277.52 billion was contributed to the MPF System. ${ }^{(36)}$ According to a consultancy report, ${ }^{\left({ }^{37}\right)}$ the MPF has a fund expense ratio (FER) amounting to $1.74 \%$ of the assets under management from 1 July 2010 to 30 June 2011, higher than those of Australia, Chile, Mexico, and the U.S. Although FER can be regarded generally as "management fees," according to the report, FER consists of management fees (charges for managing MPF funds), administrative costs, and others. Management fees amounted to $0.59 \%$, while others, including trustee profit, member rebates, sponsor charges, and other costs, added up to $0.40 \%$. Setting aside these items, the report attributes high FER to high administrative cost of $0.75 \%$. Nonetheless, the report admitted that "trustees must delegate the investment management function to investment managers, and may delegate the administration function to other parties." Thus, there "may be a profit element within the fee being charged for such delegated functions." (38) Overall, the report suggested that the FER would be driven down as the MPF grew bigger, having a limited number of large service providers, centralising administration, and using electronic solutions. ${ }^{(39)}$ However, the report also showed that the top five and ten trustees had managed $77 \%$ and $95 \%$ of all MPF assets respectively in the same period. ${ }^{(40)}$ The figures simply indicate that the MPF is a highly monopolised business. One may wonder why the government did not establish a centralised system at the outset to minimise administrative costs. As Chan points out, "It is only the MPF that can match Hong Kong's

30. Yun Chung Chen and Ngai Pun, "Neoliberalisation and Privatisation in Hong Kong after the 1997 Financial Crisis," The China Review, Vol. 7, No. 2, 2007, pp. 65-92.

31. http://hk.finance.yahoo.com/q?s=0823.HK (accessed on 24 September 2013).

32. Lusina Ho, "Mandatory Provident Funds in Hong Kong:Too Little, Too Late," Asian Journal of Public Administration, Vol. 23 No. 1, 2001, pp. 68-72.

33. Legislative Council Secretariat, Fact Sheet: Historical Development of Retirement Schemes in Hong Kong, para. 2.1, www.legco.gov.hk/yr04-05/english/sec/library/0405fs 18e.pdf (accessed on 24 September 2013).

34. Lusina Ho, "Mandatory Provident Funds in Hong Kong," art. cit., pp. 72-75.

35. Ibid., pp. 75-78.

36. Mandatory Provident Fund Schemes Authority, A 10-year Investment Performance Review of the MPF System, 2011, p. 6.

37. Ernst \& Young, Managing the Changing Landscape of Retirement Savings: Report on a Study of Administrative Costs in the Hong Kong Mandatory Provident Fund System, 2012.

38. Ibid., p. 18.

39. Ibid., p. 22.

40. Ibid., p. 15. 


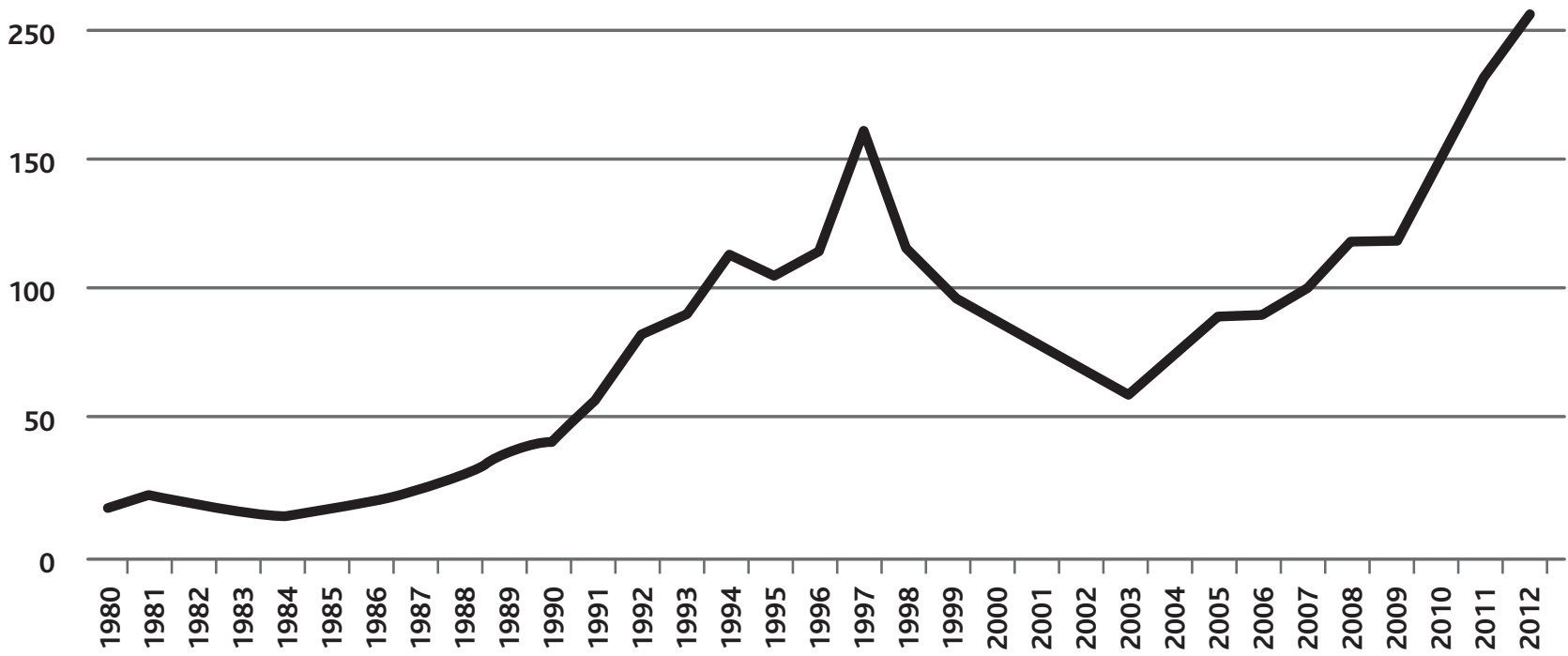

Source: Rating and Valuation Department, www.rvd.gov.hk/en/property_market_statistics/index.html (accessed on 5 February 2014)

basic and traditional principles: pursuing a low tax regime and maintaining a limited government," and "the MPF helps strengthen Hong Kong's financial services." (41)

\section{Turning Hongkongers into investors}

Alan Smart and James Lee ${ }^{(42)}$ argue that the financialisation of Hong Kong mainly depends on real estate. They are certainly right. But as property prices rise tremendously, not many Hongkongers can afford the massive down payments. Moreover, the Asian financial crisis taught investors a hard lesson. Although the government devised a number of measures to support the property markets, investors were still very cautious. The government needed another asset market to generate wealth so as to propel growth because the original plan of re-industrialising Hong Kong failed. The stock market is one of the targets.

According to the Stock Market Retail Investor Surveys, ${ }^{(43)}$ only $9 \%$ of Hong Kong adults (over 18) were stock investors who engaged in stock trading in the 12 months preceding the survey in 1992. The corresponding figure rose to $16 \%$ in 1997. The Asian financial crisis did not deter people from investing in stocks. In 2000, the figure increased to 21\%. In the 2001 Survey, the HKEx introduced the notion "retail investors" who were either stock investors or derivatives investors or both. About $20.6 \%$ of Hong Kong adults were retail investors at that time. The retail investor figure dropped to $17.5 \%$ in 2003 , but rebounded to $24.6 \%$ in 2004 and kept rising to a high of $35.8 \%$ in late 2007 and early 2008 . The figure received a minor setback and decreased slightly to $35.1 \%$ in 2009 . According to the most recent survey, the figure jumped back to $35.8 \%$, comprising 2,154,000 individuals, in 2011

The government plays an important role in turning Hongkongers into stock investors in several ways. To pursue finance-led growth, a significant portion of people have to benefit from asset price appreciation so that wealth effects can sustain a consumption level that generates sufficiently large aggregate demand to stimulate economic growth. Nevertheless, capital market inflation requires an inflow of cash or high liquidity of existing capital stocks to sustain the appreciation. In order to draw inflows of money into asset markets, as mentioned before, the government financialised public assets and set up a privately managed MPF. As the 2001 Survey shows, among the estimated 200,000 new stock investors, over half entered the Hong Kong stock market through subscribing to shares of large-scale IPOs such as MTR (53\%) and buying into the Tracker Fund (10\%). ${ }^{(44)}$ Another one is the IPO of the Link, in which the retail investors were offered a $5 \%$ discount. The re-launch of the Link was nearly 18 times over-subscribed by local investors. ${ }^{(45)}$ Regarding MPF, at the end of March 2013, around 59\% and 36\% of total assets were located in Hong Kong and in Hong Kong equities respectively. ${ }^{(46)}$ The government also issued inflation-linked bonds (iBonds) to activate the underdeveloped bond market in 2011. In his budget speech, the Financial Secretary John Tsang stated, "I believe that this will help enhance retail investors' understanding of the bond market and increase their interest in bond investment." (47)

41. Chak Kwan Chan, "Protecting the ageing poor or strengthening the market economy: The case of the Hong Kong Mandatory Provident Fund," International Journal of Social Welfare, Vol. 12, No. 2 , 2003, pp. 124-126.

42. Alan Smart and James Lee, "Financialisation and the Role of Real Estate in Hong Kong's Regime of Accumulation," art. cit.

43. The Hong Kong Exchange and Clearing Ltd (HKEx) carries out the Stock Market Retail Investor Surveys regularly. The data cited here are from various issues of the Survey, www.hkex.com.hk/eng/stat/research/research.htm (accessed in September 2013).

44. HKEx, Retail Investor Survey 2001, p. 9. The Tracker Fund was established by the government to dispose of its stock holding bought during the Asian financial crisis.

45. Hong Kong Housing Authority, Report on the Divestment Project, 2006, www.housingauthority. gov.hk/hdw/content/document/en/aboutus/ha/paperlibrary/ha/HA0106.pdf (accessed on 23 September 2013).

46. MPF Schemes Statistical Digest, June 2013, www.mpfa.org.hk/eng/information_centre/statistics/ mpf_schemes_statistical_digest/files/June\%202013\%20lssue.pdf (accessed on 24 September 2013).

47. John Tsang Chun-wah, The 2011-12 Budget Speech, Hong Kong SAR Government, para. 45. 


\section{Financialisation and economic inequality}

During industrialisation, Hongkongers could attain economic security through hard work rather than relying on government support. Hard work is no doubt still important, but its effectiveness for people in the lower strata is now largely reduced by labour markets filled with precarious employment. As Hong Kong has experienced deindustrialisation and developed itself into a global city dominated by finance and producers' services, labour markets have destabilised and income inequality has increased. ${ }^{(48)}$ Under the flexible labour markets driven by financialisation, many low-skilled workers have nonstandard employment that is low-paid and insecure. In a way, quite a number are trapped in a low-income-poverty cycle: "A vicious cycle in which their mobility is restricted to circulating among low-wage fulltime jobs, nonstandard employment, and unemployment with very few opportunities to escape beyond the low-wage labour market." "(49) As a result, they have great difficulty saving enough to deal with the economic hardship created by common risks (such as sickness and accidents) and economic risks induced by financialisation, notably economic crises. Once they lose their jobs, they may have difficulty sustaining a living.

With the ascendance of shareholder value as a result of increasing numbers of Hongkongers identifying themselves as investors, corporations have tried hard to restrain wage growth through informalising their noncore workforce through contracting out or through IT-enabled automation. Thus, economic insecurity is no longer just a concern for the poor; people in the lower-middle strata may also suffer from nonstandard employment and unstable labour markets. In today's Hong Kong, the principal source of income for these lower-middle-strata families is wage or salary work. The average family always devotes a large portion of its salaries to recurrent expenditure on education fees, mortgage payments, medical services, and other daily consumption. Frequent economic downturns induced by financialisation not only put their jobs at risk, but also deprive them of the possibility of drawing on their investments and savings to maintain their current living standards without losing wealth. The negative-asset group created by the Asian financial crisis and the group suffering from the Global Financial Crisis demonstrate the economic vulnerability of the lower-middle strata as well. Upper-middle-strata Hongkongers and the rich usually have sufficient liquid assets and cash flow to survive downturns, even crises, without needing to sell their assets at dismal prices. Although their wealth drops significantly during economic declines, it is just on paper (i.e. nominally) and temporarily. Once the economy resumes its upswing, their wealth will recover to or go beyond its previous level.

As Kim Ming Lee and Ching Yin Cheng argue, under financialisation, the real wages of workers grow slowly, if not stagnating, and capital gains rather than wages become important income sources for asset-rich Hongkongers. ${ }^{\left({ }^{50}\right)} \mathrm{AC}-$ cording to the latest Stock Market Retail Investor Survey,

"The typical Hong Kong retail stock investor was 47 years old, with matriculation or above education, a monthly personal income of about HK\$16,250 and a monthly household income of about $H K \$ 35,000$. In comparison to the Hong Kong adult population and non-investors, stock investors comprised a larger proportion of males, individuals who received tertiary or above education, individuals employed in the finance industry and individuals of higher work status, higher monthly personal income and monthly household income" (emphasis original). ${ }^{(51)}$
In 2011, the median monthly income from main employment and median monthly domestic household income was $\$ 12,000$ and $\$ 20,200$ respectively. ${ }^{(52)}$ About $34.5 \%$ of all Hong Kong households had income above $\$ 30,000$. ${ }^{(53)}$ These figures suggest that upper-middle-strata and upper-strata Hongkongers are the major retail players in the financial markets. Continuing capital market inflation and financialisation give them tremendous financial windfalls, but at the expense of non-investors, whose main sources of income are derived from wages.

Besides stock markets, property markets have been the major investment channel for Hongkongers. Nonetheless, considering the increasing land and property prices, not all Hongkongers are able to amass the huge down payment and gain access to credit to finance such an investment. Indeed, the Hong Kong real estate markets have reached a level where only uppermiddle-strata and upper-strata households can help their children enter the property ladder. This explains recent public outcries over the unaffordability of housing. Increasing housing costs also have significant implications for old-age poverty at present and in the future. High housing costs drain the current resources of lower-income people, depleting their financial capacity to support their own parents and reducing their chances of accumulating enough for their future retirement. We will now turn to this old-age poverty issue.

\section{Old-age poverty and retirement protection}

In the mid-2000s, on average, $13.5 \%$ of people over 65 in OECD countries lived in income poverty, i.e., less than the half of the national median. ${ }^{(54)}$ Using the same yardstick, the Hong Kong Council of Social Service (HKCSS) finds that the old-age poverty rate was between $32.5 \%$ and $36.4 \%$ from 2001 to the first half of 2012 (see Table 3). The figure for 2012 is 33.4\%, which means that among every three elderly, one lives in poverty. The figures are above the OECD average. Indeed, old-age poverty has been a worrisome problem in Hong Kong for decades due to the lack of a public pension. Before the establishment of the MPF, family support, personal savings, and public assistance were the main retirement protections. The current rate of old-age poverty can be regarded as the failure of the first two to provide sufficient income for the elderly poor. Besides the universal Old Age Allowance (OAA), applying for the means-tested Comprehensive Social Security Assistance (CSSA) and Old Age Living Allowance (OALA) are the only way for poor old people to support a basic living. As Table 4 shows, from 2001 to 2011, oldage cases consistently represented more than half of all CSSA cases.

According to the five-pillar pension model of the World Bank, (55) OAA, OALA, and CSSA constitute non-contributory zero pillar schemes. Nonethe-

48. For instance, see Kim Ming Lee, et al., "Social Polarisation and Poverty in the Global City: The Case of Hong Kong," China Report, Vol. 43, No. 1, 2007, pp. 1-30.

49. Kim Ming Lee and Hung Wong, "Marginalized workers in postindustrial Hong Kong," The Journal of Comparative Asian Development, Vol. 3, No. 2, 2004, p. 260.

50. Kim Ming Lee and Ching Yin Cheng, "Financialisation, Economic Crises and Social Protection: The Case of Hong Kong," Journal of Asian Public Policy, Vol. 4, No. 1, 2011, pp. 18-41.

51. HKEx, Retail Investor Survey 2011, op. cit., p. 8.

52. Census and Statistics Department, 2011 Population Census Thematic Report: Household Income Distribution in HK, Hong Kong, Hong Kong SAR Government.

53. Ibid., table 2.13b.

54. OECD, Pensions at a Glance 2011: Retirement-Income Systems in OECD and G20 Countries, Paris, OECD, 2011, p. 148

55. The World Bank Pension Conceptual Framework, http://siteresources.worldbank.org/INTPENSIONS/Resources/395443-1121194657824/PRPNoteConcept_Sept2008.pdf (accessed on 24 September 2013). 


\begin{tabular}{|c|c|c|c|c|c|c|c|c|c|c|c|c|c|c|}
\hline Year & 2001 & 2002 & 2003 & 2004 & 2005 & 2006 & 2007 & 2008 & 2009 & 2010 & 2011 & $\begin{array}{c}2012 \\
\text { (1st Half) }\end{array}$ \\
\hline $\begin{array}{c}\text { Number } \\
\text { (thousand) }\end{array}$ & 266.8 & 254.9 & 258.4 & 268.3 & 276.5 & 282.3 & 293.0 & 283.0 & 276.1 & 276.8 & 288.2 & 305.0 \\
$(36.4)$ & $(33.7)$ & $(33.4)$ & $(33.6)$ & $(34.0)$ & $(35.6)$ & $(35.8)$ & $(34.4)$ & $(33.0)$ & $(32.5)$ & $(32.7)$ & $(33.4)$ \\
\hline
\end{tabular}

* The number of people of age 65 or above with monthly household income less than or equal to the median household income of the same household size. The numbers in brackets are old-age poverty rates. Source: HKCSS, www.poverty.org.hk/povertydata?tid=28 (accessed on 5 February 2014).

less, OAA is trivial: its amount is so small that Hongkongers call it "fruit money," a token recognition of the contribution of old people to society. The other two are means-tested and target poverty alleviation. When the elderly apply for CSSA, by definition, they have very few assets, savings, or family support and are confronted with living difficulties. OALA and CSSA are merely for subsistence living. If people want to live a bit better, the only way is to get out of retirement and work. Hence, the zero-pillar in Hong Kong is merely for survival, or in the worst case, for sustaining the miserable life of the impoverished elderly.

In Hong Kong, the publicly managed mandatory and contributory firstpillar is absent. As mentioned before, there was a chance that an OPS could have been implemented in 1993. But the plan was thwarted by Hong Kong capitalists and the Chinese authorities. There are still many civil society organisations fighting for the establishment of a universal pension. Under Donald Tsang's government, officials rejected it on the pretext of a lack of consensus and the problems of a pay-as-you-go system. C. Y. Leung has promised to study the feasibility of establishing another layer of retirement protection, but has never showed any support for universal pensions.

The MPF is the mandatory second-pillar designed as a solution for Hong Kong's ageing society. However, its structural flaws have been widely discussed: its limited coverage (especially for non-working females), extremely insufficient lump sum benefits for future livelihood due to low contributions, high management fees and administrative costs, the poor financial literacy of ordinary Hongkongers in managing their account, and returns highly vulnerable to economic crises, which happen more frequently under global financialisation. The worst happens when retirees get their lump sum MPF benefits at 65 without other assets, savings, or family support, and they cannot apply for social assistance until all their MPF benefits are used up. Consequently, these elderly can expect to see their living standard decline unless they continue to work. Nonetheless, finding a job in old age is not easy, especially for workers with low skills and education. In the end, these old people need to apply for the stigmatised means-tested social assistance in order to survive.

As for the voluntary third-pillar under the World Bank model, given the high income inequality and precarious employment conditions in Hong Kong, a lot of upper-lower and lower-middle strata workers cannot save or invest adequately, if at all, to prepare for increasingly expensive life in retirement. In other words, this pillar is irrelevant to relatively low-earnings groups. On the other hand, the non-financial fourth-pillar, which includes family support, individual assets (such as homeownership), and other social programmes, is probably the major retirement protection the government relies upon. As a liberal or residual welfare regime, the government has long relied on the family to support the elderly, although the government does provide additional housing and medical services to reduce the burden on families. However, the trends of rising nonstandard employment, smaller average household size, increasing divorce rate, and declining intergenerational co-residence, together with the existing public pension system and levels of familial dependence, may expose many elderly to poverty. ${ }^{(56)}$ First, nonstandard employment reduces the resources of adult children to support their elderly parents. Second, smaller household size implies fewer siblings to help share the responsibilities. Third, rising housing costs make it hard for adult children to let their parents live with them. Even worse, as Kok-Hoe Ng argues, "When these adult children eventually retire, they may have less pension savings and possibly even fewer children of their own to support them. If current trends persist, the problem of old-age income security may compound in successive generations." (57)

According to a 2012 government survey, among the future generation of retired persons (aged 35 or above), $79.2 \%$ had some sort of retirement protection from work: the majority (68.4\%) cited the MPF. ${ }^{(58)}$ If retirement protection from work is excluded, only $50.9 \%$ had made preparations for their post-retirement financial needs through savings and investment, and $16.3 \%$ expected their children to support them when they retired. The corresponding figures for the current generation of retired persons are $39.1 \%$ and $27.1 \%$. These figures suggest that Hongkongers now rely more on their own savings and investment than on children to support their retirement, as compared to the already retired generations. The survey also found out that $40.8 \%$ (around 1.2 million) of non-retirees did not have any retirement preparation other than the retirement protection from work. (59)

If the role of family support in retirement protection is diminishing, other social programmes, such as public housing and medical services, may alleviate the devastating conditions of poor retirees. Unfortunately, as previously discussed, public social services, if not yet financialised to become commodities, are subject to the pressures of cutbacks. Thus, these social programmes will not help much, unless there is a strong political will or demand to retain their public and decommodified nature. The government has repeatedly warned the public about the ageing Hong Kong society and the related rising government expenses and contracting revenues. Its ultimate aim is to circumvent the political demands of increasing social welfare by claiming the importance of fiscal prudence. In facing the problems of future old-age poverty problems, the government has only promised to reform the existing MPF and introduced the OALA to release some political pressure. Nevertheless, the government, as usual, insists on the residual nature

56. Kok-Hoe Ng, "Review essay: prospects for old-age income security in Hong Kong and Singapore," Journal of Population Ageing, Vol. 4, No. 4, 2011, pp. 271-293.

57. Ibid., p. 288.

58. Census and Statistics Department, Thematic Household Survey Report - Report No. 52, Retirement Planning and the Financial Situation in Old age, June 2013, Hong Kong, Hong Kong SAR Government, table 9.5 .

59. Ibid., table $9.6 a$. 
of social welfare and so far has no intention of devising any long-term institution to deal with the problems. ${ }^{(60)}$

\section{Conclusion}

In this paper, we attempted to analyse Hong Kong's income polarisation and inequality from the lens of financialisation, a fresh perspective in current literature. We began by showing that the Hong Kong economy is a financeled growth regime. Then we illustrated how the government has further developed the regime through financialising public housing and retirement, thus turning ordinary Hongkongers into investors. The financialisation of the Hong Kong economy does propel economic growth through the wealth effects generated by asset prices inflation. However, at the same time, it also reinforces the already worsening economic inequality by restraining real wage growth and destabilising labour markets. Through examining the five pillars of the Hong Kong pension system, we found that the chances for low-income households to have a decent retirement life are quite slim.

Financialisation has led to a new "paradox of thrift," where low-income households face destabilised labour markets, stagnant wage growth, reduced social services, and rising housing and daily consumption costs, even though saving and investment is much encouraged by the state. They can barely make ends meet, not to mention save and invest for retirement. Without sufficient savings that can take advantage of the asset appreciation that characterises the financialised Hong Kong economy, low-income retirees have no choice but to rely on their possibly equally poor adult children, or on social assistance, after using up their MPF benefits. Taken along with the trend of declining family support as a means of retirement protection, the government needs to consider alternative ways to protect low-income households against the risk of old-age poverty. Maybe this is the time for the government to consider establishing a universal pension, the first pillar, to guarantee a minimal monthly payment for future retirees, in spite of objections from capitalists, especially the financial sector.

Kim Ming Lee is a senior lecturer in Division of Social Sciences, Community College of City University.

Division of Social Sciences, Community College of City University,

Tat Chee Avenue, Kowloon, Hong Kong (sckimlee@cityu.edu.hk).

I Benny Ho Pong To is a lecturer in Division of Social Sciences, Community College of City University.

Division of Social Sciences, Community College of City University,

Tat Chee Avenue, Kowloon, Hong Kong (tohopong@cityu.edu.hk).

I Kar Ming Yu is an assistant professor, associate head in the Department of Asian and Policy Studies and director in the Unit of Associate Degree Studies, Hong Kong Institute of Education. Department of Asian and Policy Studies, Hong Kong Institute of Education, 10 Lo Ping Road, Tai Po, N.T. Hong Kong (yukm@ied.edu.hk).

60. A recent related initiative by the Hong Kong government is to encourage "reverse mortgage" schemes, where a loan, made against property owned by the debtor, becomes repayable when the borrower dies or leaves their residence permanently. Reverse mortgage represents another example of financialisation of welfare, and it would seem that the "asset-rich but income-poor" may benefit from the scheme. A full review of the reverse mortgage program in Hong Kong, which is still in its early stage, is beyond the scope of this article. Two preliminary remarks should suffice here. First, possibly because of cultural factors, reverse mortgages do not seem to be very well received among the retired in Hong Kong. Second, and more importantly, reverse mortgages - like the MPF scheme - benefit only those who are wealthy enough to own assets (invest). It therefore seems unlikely that reverse mortgage schemes would address the thrust of this article. 